M.A. Nazarkovsky ${ }^{1}$, V.M. Gun'ko ${ }^{1}$, G. Wójcik ${ }^{2}$, B. Czech ${ }^{2}$, A. Sobieszek ${ }^{2}$, J. Skubiszewska-Zięba ${ }^{2}$, W. Janusz ${ }^{2}$, E. Skwarek ${ }^{2}$

\title{
BAND-GAP CHANGE AND PHOTOCATALYTIC ACTIVITY OF SILICA/TITANIA COMPOSITES ASSOCIATED WITH INCORPORATION OF CuO AND NiO
}

\author{
${ }^{1}$ Chuiko Institute of Surface Chemistry of National Academy of Sciences of Ukraine \\ 17 General Naumov Str., Kyiv, 03164, Ukraine, E-mail: nazarkovsky.michael@gmail.com \\ ${ }^{2}$ Maria Curie-Skłodowska University, Faculty of Chemistry \\ 3 Maria Curie-Skłodowska pl., Lublin, 20031, Poland
}

The $\mathrm{CuO}$ and $\mathrm{NiO}$ doped silica/titania nanocomposites were investigated using ultraviolet-visible light diffuse reflectance spectroscopy (UV-Vis DRS) and X-ray photoelectron spectroscopy (XPS). The photocatalytic activity of the samples was studied in photooxidation of caffeine $(C A F)$. The band gaps were calculated using the Tauc plot for non-direct allowed optical transitions except a system at $C_{N i O}=30 \mathrm{wt} . \%$ analyzed using a direct allowed optical transition. Copper oxide concentration increase leads to almost exponential diminution of the band gap. The band gap of $\mathrm{NiO}$ doped composites demonstrates almost linear change with $C_{N i O}$. According to the XPS data, the doping oxides are completely absent at a composite surface. All the composites are shown to be more effective photocatalysts than titania Degussa P25.

Keywords: titania, caffeine, P25, XPS, photocatalysts, Heraeus reactor, $\mathrm{CuO}, \mathrm{NiO}$

\section{INTRODUCTION}

Band gap structure of $\mathrm{TiO}_{2}$ The band gap $\left(\mathrm{E}_{\mathrm{g}}\right)$ belongs to the most important features of semiconductor catalysts. Titania and $\mathrm{TiO}_{2}$ based semiconductors are of a considerable interest as catalysts, sensors, implants, medical media, corrosion protectors and electronic components widely studied and used in a variety of physicochemical, biological and industrial processes [1-15]. Introducing dopants of multifarious characters (metals, nonmetals) [16-22] involves the band gap narrowing of titania materials which gives rise to energy saving for diverse technological purposes.

The ultraviolet-visible (UV-Vis) spectroscopy is one of appropriate techniques for the band gap estimation [23-26]. It can be applied to calculate the $E_{g}$ values of amorphous materials with properties regarding the band theory manifested even at so-called size quantization effects. The size quantization effects may be caused by two reasons. The first one is due to a high dispersity of nanomaterials, i.e. the amounts of the surface and in-bulk atoms are comparable. Consequently, there is domination of the surface imperfection over the physicochemical properties which are usually dictated with the bulk grating molecular structure in monolith solids. The second reason lies in the fact that the de Broglie wavelength of electron (or hole) and a particle size are commensurate. The charge carriers are considered like particles confined in a quantum-mechanical box. The space of this box is limited by the particle size under such conditions. The low-dimensional particles are defined by several authors as Q-particles [27-31]. The band gap undergoes broadening in terms of the quantum size effect, what is conventionally described by Brus's equation [32] modified by Kayanuma [33] and other authors [34-37]:

$$
\Delta \mathrm{E}_{\mathrm{g}}=\frac{\pi^{2} \mathrm{~h}^{2}}{2 \mathrm{r}}\left(\frac{1}{\mathrm{~m}_{\mathrm{e}}^{*}}+\frac{1}{\mathrm{~m}_{\mathrm{h}}^{*}}\right)-\frac{1.786 \mathrm{e}^{2}}{\varepsilon \mathrm{r}}-0.248 \mathrm{E}_{\mathrm{Ryd}}^{*},
$$

where $r$ is the particle radius, $\mathrm{m}_{\mathrm{e}}^{*}$ is the effective electron mass, $\mathrm{m}_{\mathrm{h}}^{*}$ is the effective hole mass, $\varepsilon$ is the relative permittivity, $\mathrm{h}$ is Planck's constant, $\mathrm{e}$ is the electron charge, and $E_{\mathrm{Ryd}}^{*}$ is the effective Rydberg energy $\left(4.3 \times 10^{-39} \mathrm{~J}\right)$. To put it differently, the $E_{\mathrm{g}}$ values of extremely small particles (1-10 nm according to $[27,29])$ are higher than ones of continuous solid bodies. By way of illustration 
(Fig. 1), let us show the energy level distribution cited as an example from [27].

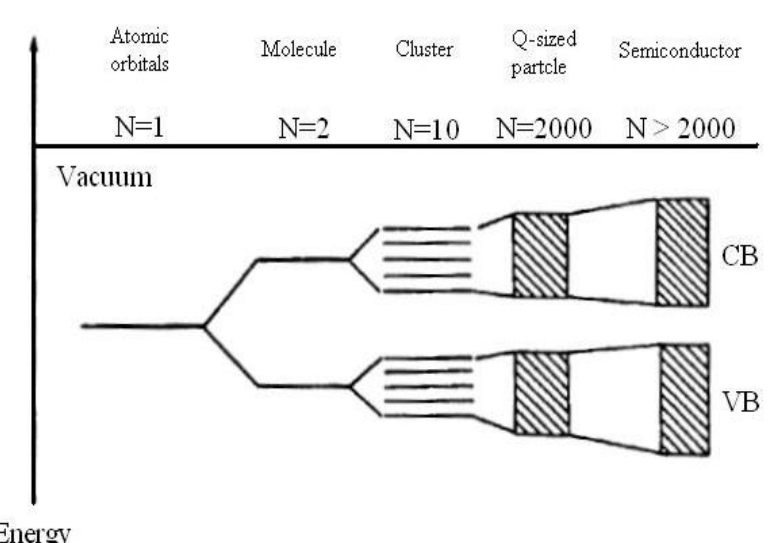

Fig. 1. Energy level $(\mathrm{N})$ distribution for different systems [27]

The Q-sized particles are intermediates in the energy level distribution between a molecule and a bulky semiconductor. The Q-particle band gap blueshift $\left(\Delta \mathrm{E}_{\mathrm{g}}\right)$ takes values around $0.1-0.2 \mathrm{eV}$ of the massive semiconductor $\mathrm{E}_{\mathrm{g}}[24,27]$, e.g. the band gap of the commercial $\mathrm{TiO}_{2}$ sample is $3.2 \mathrm{eV}$

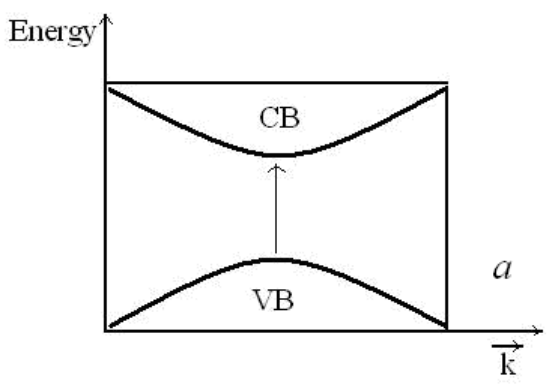

$[24,38,39]$ which corresponds to anatase band gap. Thus, the $\mathrm{E}_{\mathrm{g}}$ of nanotitania estimated by the $\mathrm{UV}-\mathrm{Vis}$ spectroscopy is around $3.4 \mathrm{eV}$. It is worthy to note that there are two types of the band gaps such as direct and indirect ones. Anatase and rutile band gaps are different not only in values, but also in positions of the valence and conduction bands (VB and CB, respectively) (Fig. 2) [40-42].

If the boundaries of the energy bands are so located that the conduction band minimum tops over the valence band maximum (Fig. $2 a$ ), the momentum conservation law will be kept by the electron-photon interaction:

$\vec{P}_{V}+\vec{P}_{*}=\vec{P}_{C}$

where $\overrightarrow{\mathrm{P}}_{\mathrm{V}}$ and $\overrightarrow{\mathrm{P}}_{\mathrm{C}}$ are the electron momenta of the valence and conduction bands respectively, $\overrightarrow{\mathrm{P}}_{*}$ is the photon momentum. In an indirect gap, an electron cannot pass from the conduction band to the valence band without a change of momentum which is transferred to a phonon or is taken away from it (Fig. $2 b$ ).

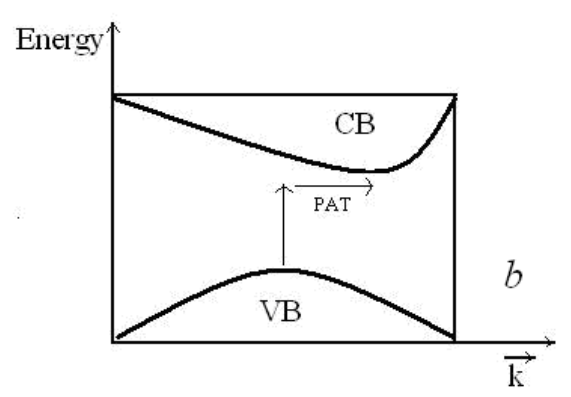

Fig. 2. Energy $v s$. wave vector of $(a)$ direct and $(b)$ an indirect band gap semiconductors. VB - valence band, CB conduction band, PAT - photon assisted transition of an electron

Use of $\mathrm{TiO}_{2}$ for photocatalytic destruction of caffeine (CAF). Recently, a new group of emerging contaminants called as pharmaceuticals and personal care products (PPCPs) has attracted considerable interest because of their harmful effect upon the environment and living organisms [43-45]. The structure of all PPCPs governs a biological effect what means that they are usually persistent against biodegradation and natural attenuation [45-48]. The main source of those compounds in the environment is domestic and hospital wastewater containing metabolized and non-metabolized (1) drugs, (2) drugs remains and (3) drug packaging [47, 49, 50].
In the aqueous surroundings the concentration of PPCPs is ranging from $\mathrm{ng} / \mathrm{L}$ up to $\mu \mathrm{g} / \mathrm{L}$ [51]. Hence, the removal of these compounds from wastewater by conventional treatment is indicated to be insufficient because treatment plants are not designed to remove persistent pollutants at low concentrations.

One of the PPCPs that can be recognized as a truly anthropogenic pollutant in aqueous ecosystem is caffeine $(1,3,7$-trimethyl- $1 \mathrm{H}$-purine-2,6 $(3 \mathrm{H}, 7 \mathrm{H})$ dione, CAF). CAF was determined in water, wastewater, lake water and ground water in $\mathrm{ng} / \mathrm{L}$ concentrations [52]. In some instances CAF 
concentration has been shown to be high enough to have a toxic effect on the living organisms [53].

A correlation between CAF concentration and bacteria presence in water was shown in [54] what substantiates the role of CAF as indicator of water contamination. The degradation of CAF lasts 2-3 months depending on the environment, but the concentration of $400 \mathrm{ng} / \mathrm{L}$ is enough to establish the presence of coli forms. Advanced Oxidation Processes and photocatalysis are characterized by high efficiency of the removal different persistent organic and inorganic pollutants [55]. The application of $\mathrm{TiO}_{2}$ enables the mineralization of compounds into $\mathrm{CO}_{2}, \mathrm{H}_{2} \mathrm{O}$ and simple inorganic ions [56]. Beside unquestionable advantages (low price, stability, reactivity, safety), $\mathrm{TiO}_{2}$ features two main disadvantages: powdered form and low activity in Vis region what is associated with the application of energy produced by UV lamps. These disadvantages can be however overcome by various ways of modification. Transition metals are recognized as the factors enhancing $\mathrm{TiO}_{2}$ activity.

Summing it up, this paper focuses on investigations of (1) the ultraviolet-visible diffuse reflectance spectra of novel $\mathrm{CuO}$ and $\mathrm{NiO}$ doped nanosilica/titania composites, (2) the dopant concentrations influence on the $\mathrm{E}_{\mathrm{g}}$ of the $\mathrm{TiO}_{2}$-containing materials, and (3) their photocatalytic activity in UV region. The presence of dopants at a composite surface or only interior the particles may influence different changes in the band gap exerting absorption of different energy amount. The photocatalytic activity of nanosilica/titania composites have been studied more widely and thoroughly [57-68] than MO-doped $\mathrm{SiO}_{2} / \mathrm{TiO}_{2}$ (M: Cu or Ni) systems.

\section{MATERIALS AND METHODS}

The silica/titania composites modified by $\mathrm{CuO}$ and $\mathrm{NiO}$ were synthesized through successive hydrolytic deposition of dopants precursors $\mathrm{Ni}\left(\mathrm{NO}_{3}\right)_{2}$ (Macrokhim, pure) or $\mathrm{Cu}\left(\mathrm{CH}_{3} \mathrm{CO}_{2}\right)_{2}$ (Makrokhim, pure) and $\mathrm{TiCl}_{4}$ (Sigma Aldrich, $99.9 \%$ ) on a surface of nanosilica A-300 $\left(S_{\mathrm{BET}}=294 \mathrm{~m}^{2} / \mathrm{g}\right.$, pilot plant at Chuiko Institute of Surface Chemistry, Kalush, Ukraine). Nanosilica was introduced into a reactor after pre-heating at $450{ }^{\circ} \mathrm{C}(6 \mathrm{~h})$. Then the saturated solution of the dopants precursors was added. The synthesis was carried out in dry air atmosphere at $100{ }^{\circ} \mathrm{C}$ in a glass reactor fitted with a Teflon stirrer. To eliminate $\mathrm{HCl}$, the reactor was blown out with air. The obtained products were calcined at $600{ }^{\circ} \mathrm{C}$ to form photoactive anatase doped by $\mathrm{Ni}^{2+}$ or $\mathrm{Cu}^{2+}$ formed due to precursor thermolysis

$$
\begin{aligned}
& 2 \mathrm{Ni}\left(\mathrm{NO}_{3}\right)_{2}=2 \mathrm{NiO}+4 \mathrm{NO}_{2}+\mathrm{O}_{2}, \\
& \mathrm{Cu}\left(\mathrm{CH}_{3} \mathrm{CO}_{2}\right)_{2}+4 \mathrm{O}_{2}=\mathrm{CuO}+4 \mathrm{CO}_{2}+3 \mathrm{H}_{2} \mathrm{O} .
\end{aligned}
$$

Each composite contains 15 wt. $\% \mathrm{TiO}_{2}$. The concentrations of dopants $(\mathrm{CuO}$ and $\mathrm{NiO})$ range from 0.14 up to 30 wt. $\%$ in respect to $\mathrm{TiO}_{2}$.

The (UV-Vis) spectra were recorded using an Jasco V-660 spectrophotometer fitted with a PIV-756 diffuse reflectance accessory in the $200-900 \mathrm{~nm}$ wavelength range with a scanning rate of $400 \mathrm{~nm} / \mathrm{min}$. Zinc oxide was used as a reference sample. The UV-Vis spectra were transformed to the diffuse reflectance ones using the KubelkaMunk formalism [69]:

$\mathrm{K}=\frac{(1-\mathrm{R})^{2}}{2 \mathrm{R}}$,

where $K$ is the reflectance transformed according to Kubelka-Munk, $R$ is the reflectance obtained from the UV-Vis spectra (\%).

The band gap values were calculated using the Tauc method [24, 25, 70,71] adapted for an indirect gap (for an anatase containing system) and for a direct one (for a rutile containing system). The respective plots are expressed in terms of $(\alpha h v)^{2} v s . h v$ for a direct and $(\alpha h v)^{1 / 2} v s . h v$ for an indirect band gaps, where $\alpha$ is the absorption coefficient and $h v$ is a photon energy.

The X-ray photoelectron spectroscopy (XPS) data were obtained using a Detector Scienta R4000 and Prevac RS 40B1-type Al/Mg-based twin anode as the X-ray source.

The photocatalytic activity of the materials was tested in the decomposition of caffeine (CAF) (Sigma-Aldrich). The model solution of caffeine containing $10 \mathrm{mg} / \mathrm{L}$ of $\mathrm{CAF}$ was prepared using distilled water. The activity of photocatalysts was measured in the course of the photocatalytic oxidation of CAF in an Heraeus photochemical reactor $(0.75 \mathrm{~L})$ equipped with a TQ 150 lowpressure UV lamp $(\lambda=254 \mathrm{~nm})$.

The model solution $(10 \mathrm{mg} / \mathrm{L} \mathrm{CAF}$ and $0.5 \mathrm{~g} / \mathrm{L}$ of a photocatalyst) placed in the reactor was stirred (500 rpm) and kept in dark for $30 \mathrm{~min}$ to reach the adsorption-desorption equilibrium. The first sample was taken at the end of the "dark" period, and then samples were taken in regular intervals during $2 \mathrm{~h}$. To study the kinetics, eight centrifuged samples were analyzed by High Performance Liquid Chromatography (HPLC) using a Diode Array 
Detector (Waters) with a C18 Waters PAH column in a mixture of acetonitrile and water as a mobile phase $\left(\mathrm{ACN}: \mathrm{H}_{2} \mathrm{O}\right.$ 50:50) with a flow rate of $0.5 \mathrm{ml} / \mathrm{min}$. CAF was detected at $\lambda=281 \mathrm{~nm}$. The photooxidation study with commercially available titania P25 Evonik (anatase : rutile $=80: 20$ ) as a reference material was also carried out.

The results describing the destruction of CAF were presented as $c / c_{0} v s$. time $t$, where $c$ was the concentration of CAF determined at time $t$ and $c_{0}$ was the initial concentration of CAF.

\section{RESULTS AND DISCUSSION}

UV-VIS (DRS) measurements. The UV-Vis absorption spectra of the $\mathrm{CuO}$ and $\mathrm{NiO}$ modified silica/titania samples (Fig. 3) reveal a characteristic absorption band at $\lambda=248 \mathrm{~nm}$ due to charge transfer from $2 p$-levels of $\mathrm{O}$ atoms to $3 d$-levels of

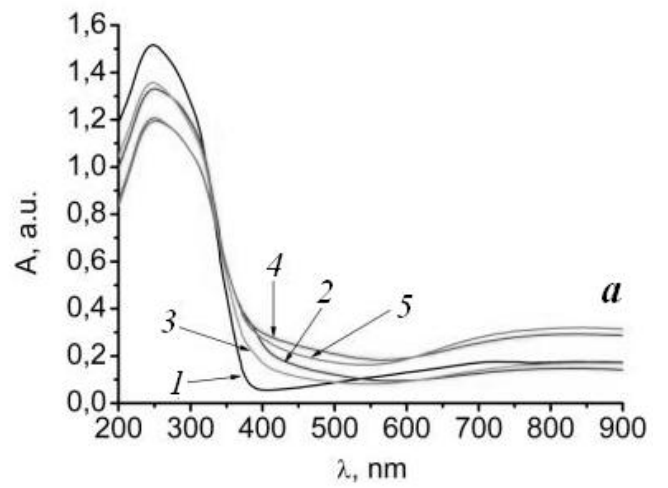

Ti (Fig. 3). In fact, the VB top is composed of the $2 p$ orbitals of $\mathrm{O}$ atoms and the $\mathrm{CB}$ bottom is composed of vacant $3 d$ orbitals of $\mathrm{Ti}$ atoms $[72,73]$. The only intensive position found is due impossible $d-d$ transition in $\mathrm{Ti}^{4+}\left(3 d^{0}\right)$. However, all the samples are characterized by the presence of light absopriton both in UV and visible fields.

Low-intensity $d$ - $d$ transitions are situated chiefly in near IR, visible and near UV spectral regions. By this means, a broad band found at red edge of CuO-containing composites (>600 nm) is caused by octahedral crystal field splitting of $\mathrm{Cu}^{2+}$ $\left(3 d^{9}\right)$ in coordination environment of oxygen atoms and is corresponding to electron transition from $d_{\mathrm{xz}}$ or $d_{\mathrm{xy}}$ to $d_{\mathrm{x}-\mathrm{y}}^{2}$ (Fig. 4). Distortion effect described by Jan-Teller due to degeneracy of energy levels does not influence the bands positions and shapes.

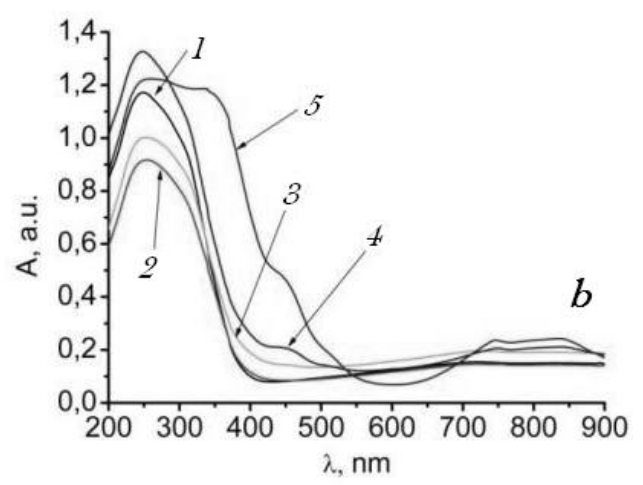

Fig. 3. The UV-Vis spectra of silica/titania doped by (a) $\mathrm{CuO}$ and (b) $\mathrm{NiO}$ at $\mathrm{C}_{\text {dop }}=0.14(1), 1(2), 5(3), 10(4)$ and 30 (5) wt. \%

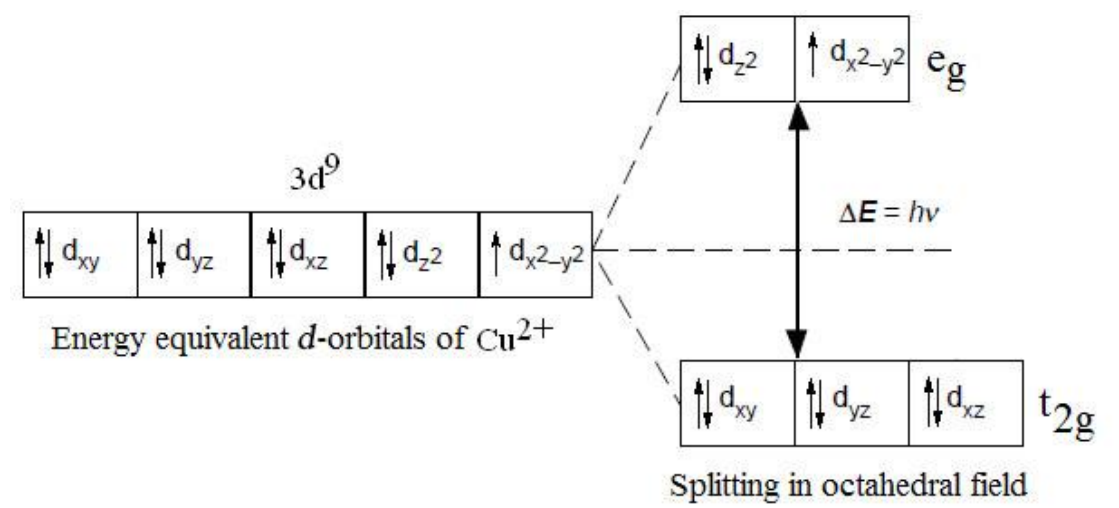

Fig. 4. Splitting of $d$-orbitals in octahedral coordination environment $\left(\mathrm{CuO}_{6}\right)$

All the $\mathrm{CuO}$ containing composites harbor only anatase. They demonstrate an absorption increase in the visible light range $(\lambda>400 \mathrm{~nm})$ with increasing dopant concentration (Fig. $3 a$ ).
The doping oxide does not provoke a bathochromic (red) shift of the charge transfer band. Notice that the charge transfer peak intensity tends to be reduced by an increase in the dopant 
concentrations. $\mathrm{Cu}^{2+}$ ion is characterized only by unsplittable ${ }^{2} \mathrm{D}$ term corresponding to ${ }^{2} \mathrm{~T}_{2 \mathrm{~g}} \rightarrow{ }^{2} \mathrm{E}_{2 \mathrm{~g}}$ transition in the visible light range.

For $\mathrm{NiO}$ doped samples, the dopant causes a monotonous trend of the visible light absorption increase (Fig. 3 b). The sample at $\mathrm{C}_{\mathrm{NiO}}=30$ wt. \% exhibits the most considerable interest. It has the broadest band which covers both UV and visible light ranges. There are absorption onsets of rutile and nickel titanate $\left(\mathrm{NiTiO}_{3}\right)$. In fact, the latter causes the uniformly yellow-colored composite formed after the calcination. The occurrence of rutile and $\mathrm{NiTiO}_{3}$ in the $\mathrm{NiO}-\mathrm{TiO}_{2}$ systems was studied previously [74-77]. But it was stated [77] that the $\mathrm{NiO}-\mathrm{TiO}_{2}$ system obtained using the same precursors $\left(\mathrm{TiCl}_{4}\right.$ and $\left.\mathrm{Ni}\left(\mathrm{NO}_{3}\right)_{2} \cdot 6 \mathrm{H}_{2} \mathrm{O}\right)$ did not give rise to anatase-to-rutile transition even at $800-850^{\circ} \mathrm{C}$ calcinations with complete formation of nickel titanate. While the rutile-nickel(II) oxide system did not give the nickel titanate phase at that temperature range.

$\mathrm{Ni}^{2+}$ ions inherent in octahedral coordination surrounding like $\mathrm{Cu}^{2+}$ too (Fig. 5).

Let us consider the bands in the visible light range in details. There are two bands at $\lambda=450$ and $800 \mathrm{~nm}$ in the sample at $\mathrm{C}_{\mathrm{NiO}}=10$ wt. \% (Fig. $3 \mathrm{~b}$, curve 4) observed. Absorption profiles of the sample at $\mathrm{C}_{\mathrm{NiO}}=30 \mathrm{wt}$. \% (Fig. $3 b$, curve 5) is notable for bands in UV $(\lambda=350 \mathrm{~nm})$ and visible light $(\lambda=450,530$ and $800 \mathrm{~nm})$ ranges. Similar situation was found in [78-82]. The positions of the bands defined using the Tanabe-Sugano diagrams [83] accord with ${ }^{3} \mathrm{~A}_{2 \mathrm{~g}} \rightarrow{ }^{3} \mathrm{~T}_{1 \mathrm{~g}}$ of ${ }^{3} \mathrm{P}$ term $(530 \mathrm{~nm})$ and ${ }^{3} \mathrm{~A}_{2 \mathrm{~g}} \rightarrow{ }^{3} \mathrm{~T}_{1 \mathrm{~g}}$ of term ${ }^{3} \mathrm{~F}(450 \mathrm{~nm})$ transitions. Appreciable absorption at $800 \mathrm{~nm}$ can be attributed to ${ }^{3} \mathrm{~A}_{2 \mathrm{~g}} \rightarrow{ }^{3} \mathrm{~T}_{2 \mathrm{~g}}$ transition of ${ }^{3} \mathrm{~F}$ term. The availability of the band at $\lambda=350 \mathrm{~nm}$ may be explained in terms of $\mathrm{O} \rightarrow \mathrm{Ti}$ charge transfer inside nickel titanate structure [82, 84].

The quantitative characteristics of the interplay of the doped silica/titania systems and the UV-Vis light are estimated from the diffuse reflectance spectra (DRS). As depicted in Fig. 5, all the CuO-doped systems show identical forms of the curves. There is a tendency for the $\mathrm{E}_{\mathrm{g}}$ values to get depressed (Fig. $6 f$ ). This trend is manifested with a closely exponential character. Hence, cupric oxide even deposited under the $\mathrm{TiO}_{2}-\mathrm{SiO}_{2}$ layer definitely produces the band gap narrowing.

The DRS data of the systems doped by NiO display the congruent $\mathrm{E}_{\mathrm{g}}$ level decrease from 3.28 to $3.04 \mathrm{eV}$ (Fig. 7). At the highest concentration of the dopant $(\mathrm{C}=30 \mathrm{wt}$ \% \%) there are two absorption edges that can be associated with two different phases (Fig. $7 e$ ). The positions of the absorption edges have been fixed by the approach for a direct band gap, because the composite sample contains rutile. Thus, its value is a little smaller $(3.04 \mathrm{eV})$ than that of anatase.

The absorption edge conforming to $3.46 \mathrm{eV}$ may be considered as an extrinsic absorption because of the its insignificant presence in parallel with the main edge at $\mathrm{C}_{\mathrm{NiO}}=10$ wt. \% (Fig. $7 d$ ). But it is clearly in view at $\mathrm{C}_{\mathrm{NiO}}=30$ wt. $\%$ which may be assigned to the nickel titanate phase $[81,85]$ taking into account $\mathrm{E}_{\mathrm{g}}$ increase owing to size of the particles $(d=9.6 \mathrm{~nm})$. This fact correlates well with XRD patterns published previously [75, 86] (Fig. 8).

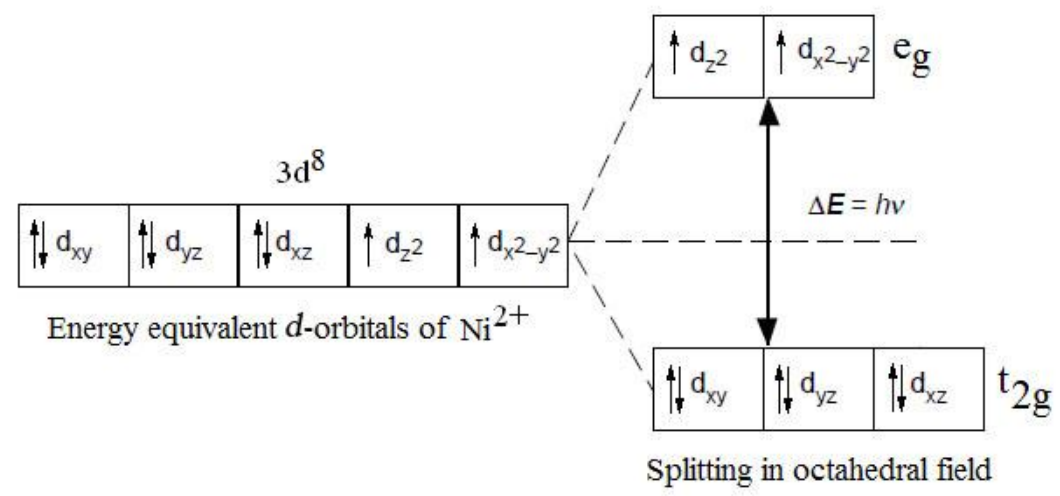

Fig. 5. Splitting of $d$-orbitals in octahedral coordination environment $\left(\mathrm{NiO}_{6}\right)$ 

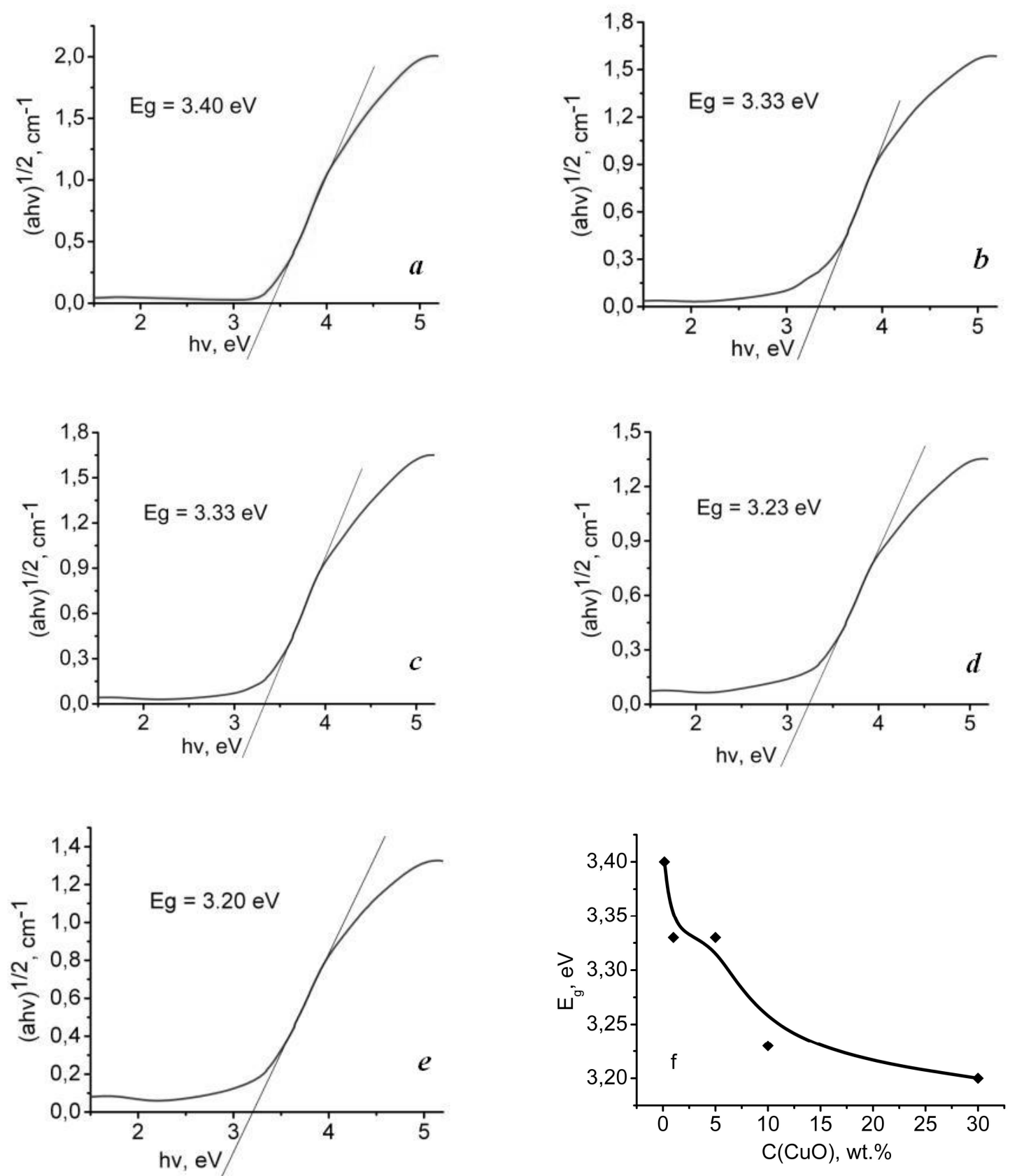

Fig. 6. The diffuse reflectance spectra of the CuO-doped silica/titania composites at $\mathrm{C}_{\mathrm{CuO}}=0.14(a), 1(b), 5(c), 10(d)$, 30 (e) wt. \% and band gap change vs. $\mathrm{CuO}$ concentration $(f)$ 

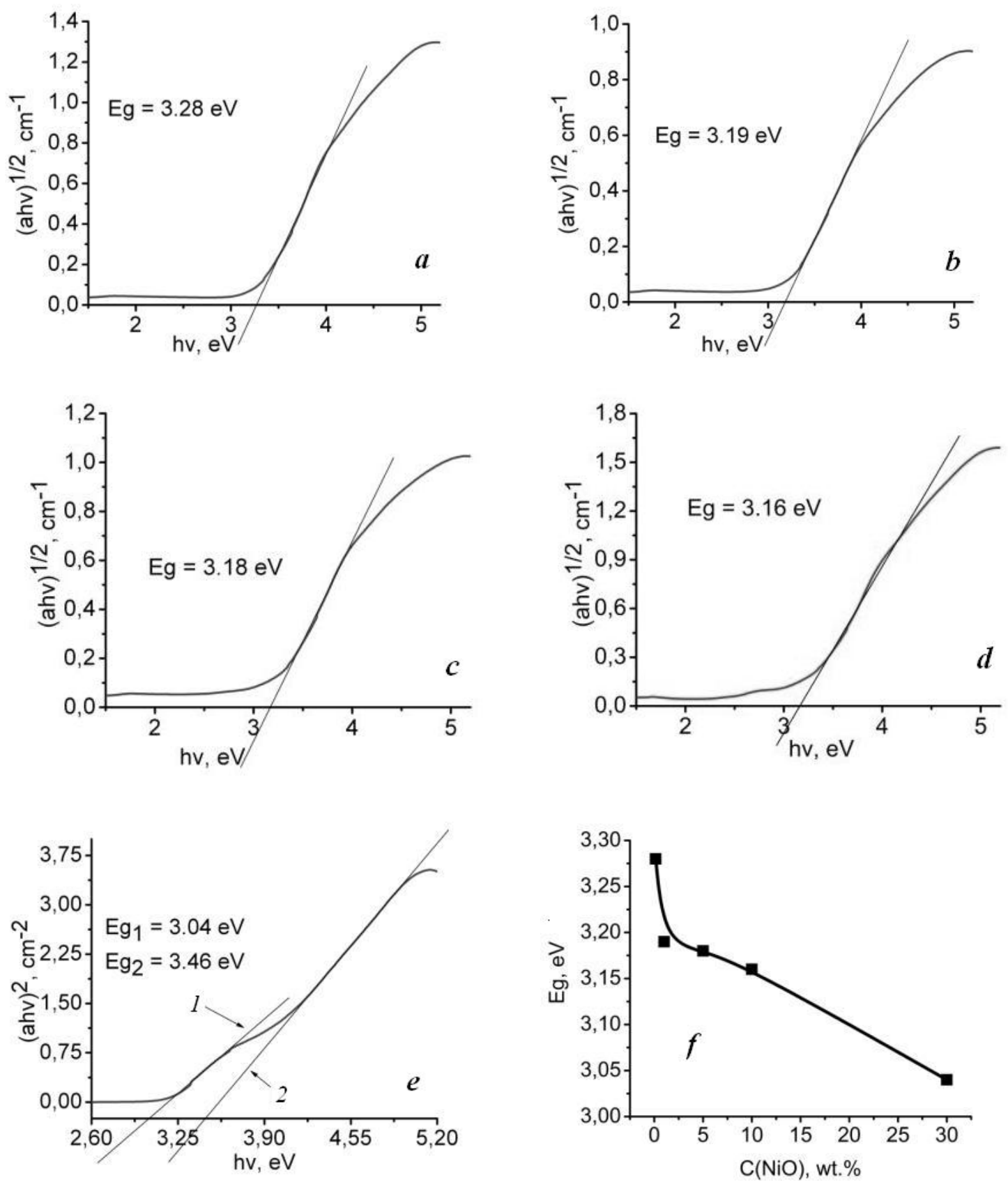

Fig. 7. The diffuse reflectance spectra of the NiO-doped silica/titania composites at $\mathrm{C}(\mathrm{NiO})=0.14(a), 1(b), 5(c), 10$ $(d), 30(e)$ wt. \% and band gap change vs. $\mathrm{NiO}$ concentration $(f)$ 

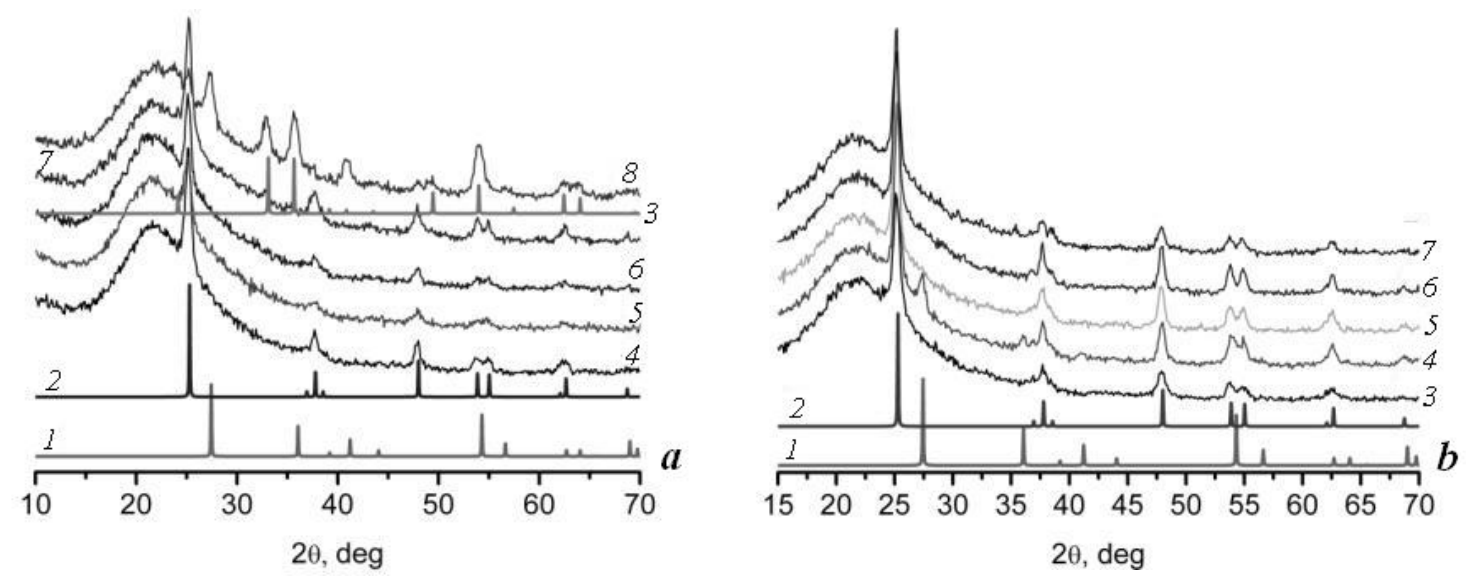

Fig. 8. X-ray diffraction patterns of crystalline rutile (1), anatase (2), nickel titanate (3a), oxide systems $\mathrm{SiO}_{2} / \mathrm{TiO}_{2} / \mathrm{NiO}_{(a)}$ at $\mathrm{C}=0.14$ (4), 1 (5), 5 (6), 10 (7), 30 (8) wt. \% and $\mathrm{SiO}_{2} / \mathrm{TiO}_{2} / \mathrm{CuO}(b)$ at $\mathrm{C}=0.14$ (3), 1 (4), 5 (5), 10 (6), 30 (7) wt. \% $[75,86]$. Copyright (C) 2014, Pleiades Publishing Ltd

XPS analysis. To gain a better understanding structure of the materials, the XPS is complementary to the XRD analysis.

Both composites give no signals respective to the doping $\mathrm{Cu}^{2+}$ and $\mathrm{Ni}^{2+}$ ions in the oxide forms (Fig. 9). According to the literature [87-89], the bonding energy (BE) peak positions for $\mathrm{Cu} 2 p$ and Ni2 $p$ are 934 and $854 \mathrm{eV}$, respectively.

The signals associated with the dopants are completely absent in the plots. But there are a couple of clearly defined peaks of silicon ( $\mathrm{Si} 2 s$ and $\mathrm{Si} 2 p$ ), weak signal of titanium (Ti2 $p$ ) and very intensive peak of oxygen $(\mathrm{O} 1 s)$. All the surface concentrations for both composites are given in Tables 1 and 2. Absence of $\mathrm{CuO}$ or $\mathrm{NiO}$ signals in the XRD and XPS plots leads us to suggestion that $\mathrm{NiO}$ or $\mathrm{CuO}$ can be incorporated into crystalline $\mathrm{TiO}_{2}$. The XPS data confirm the fact of dopants presence within the thickness of the silica-titania composites. The highest concentrations of $\mathrm{Si} 2 p$ and $\mathrm{O} 1 s$ are observed because the nanosilica support phase concentration is 85 wt. \%.

As for $\mathrm{C} 1 s(\mathrm{C}=0.78$ wt. \%), its presence may be explained by residual traces of organics, usually present inside the XPS equipment.
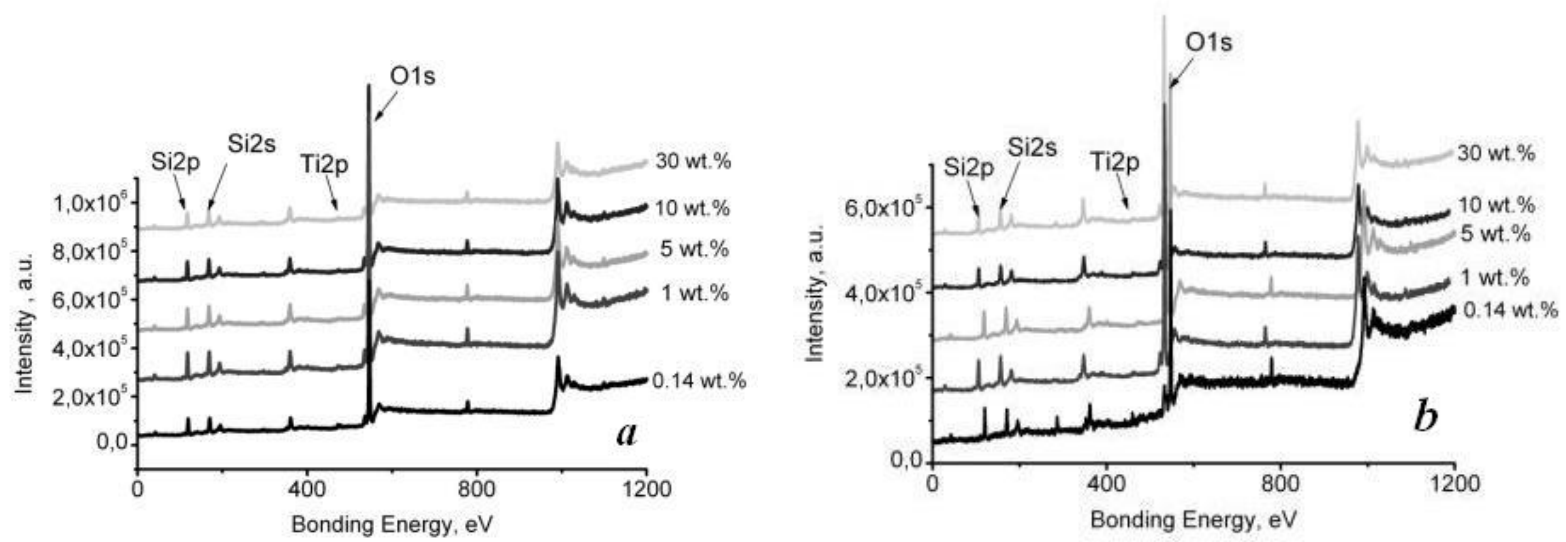

Fig. 9. The XPS spectra of the $\mathrm{CuO}(a)$ and $\mathrm{NiO}(b)$ doped silica/titania composites 
Table 1. Mass concentrations of the elements $\%$ at the surface of the $\mathrm{CuO}$ doped silica/titania composites at different dopant concentrations

\begin{tabular}{cccccc}
\hline \multirow{2}{*}{ Element } & \multicolumn{5}{c}{ CuO content (wt. \%) in doped silica/titania composite } \\
\cline { 2 - 6 } & $\mathbf{0 . 1 4}$ & $\mathbf{1 . 0}$ & $\mathbf{5 . 0}$ & $\mathbf{1 0 . 0}$ & $\mathbf{3 0 . 0}$ \\
\hline $\mathrm{O} 1 s$ & 57.12 & 57.67 & 57.87 & 57.99 & 54.57 \\
$\mathrm{Si} 2 p$ & 40.62 & 40.69 & 41.39 & 40.93 & 42.86 \\
$\mathrm{Ti} 2 p$ & 2.26 & 1.65 & 0.74 & 1.09 & 2.57 \\
\hline
\end{tabular}

Table 2. Mass concentrations of the elements $\%$ at the surface of the NiO modified silica/titania composites at different dopant concentrations

\begin{tabular}{cccccc}
\hline \multirow{2}{*}{ Element } & \multicolumn{5}{c}{ NiO content $($ wt. \%) in doped silica/titania composite } \\
\cline { 2 - 5 } & $\mathbf{0 . 1 4}$ & $\mathbf{1 . 0}$ & $\mathbf{5 . 0}$ & $\mathbf{1 0 . 0}$ & $\mathbf{3 0 . 0}$ \\
\hline $\mathrm{O} 1 s$ & 52.57 & 58.38 & 67.24 & 54.56 & 54.1 \\
$\mathrm{Si} 2 p$ & 45.64 & 39.43 & 29.82 & 44.77 & 44.19 \\
$\mathrm{Ti} 2 p$ & 1.78 & 1.42 & 2.94 & 0.68 & 1.71 \\
$\mathrm{C} 1 s$ & & 0.78 & & \\
\hline
\end{tabular}

Photocatalytic degradation of caffeine (CAF). The application of $\mathrm{CuO}$-modified $\mathrm{TiO}_{2}$ catalysts has enhanced treatment of wastewater containing CAF. All CuO-doped photocatalysts enable better removal of CAF than standard titania P25 photocatalyst. The impact of direct UV photolysis of CAF can be omitted [90] confirming occurring the process at the surface of studied materials. In all cases the addition of $\mathrm{CuO}$ results in the increased destruction of the pollutant. The highest changes in the water quality were observed after $15 \mathrm{~min}$ of treatment.

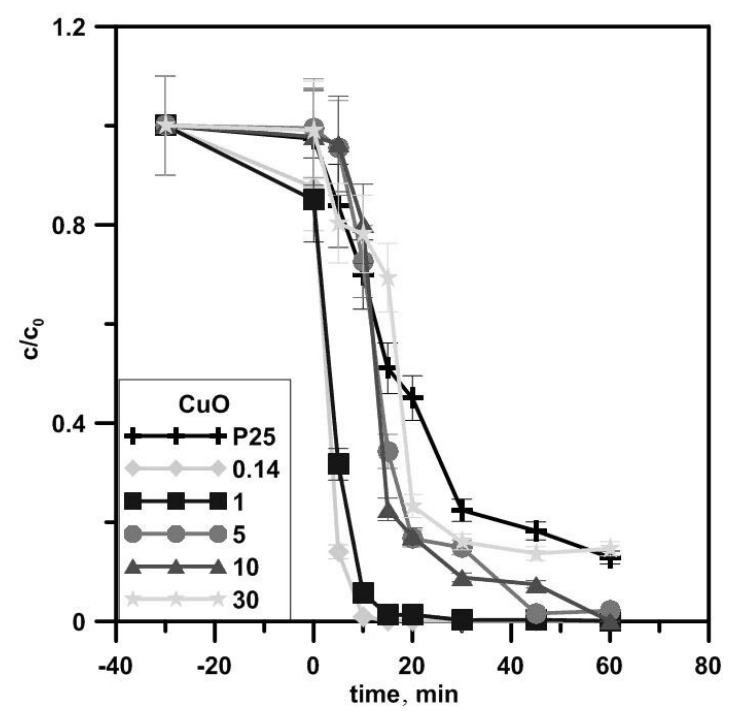

Fig. 10. The photocatalytic destruction of CAF $(10 \mathrm{mg} / \mathrm{L})$ using $\mathrm{SiO}_{2} / \mathrm{TiO}_{2} / \mathrm{CuO}$ and P25 (Evonik) $(0.5 \mathrm{~g} / \mathrm{L})$

The further extension of UV irradiation has resulted in total elimination of CAF but mainly for the photocatalysts with low $\mathrm{CuO}$ loadings. These observations confirm the results found for peroxymonosulfate activated Co-MCM41 whereas CAF was completely degraded in $20 \mathrm{~min}$ [91].

According to our results, $95 \%$ CAF photodegradation was observed after $10 \mathrm{~min}$ using the lowest $\mathrm{CuO}$ amount, but the presence of $\mathrm{CuO}$ at higher concentration (above 5 wt. \%) is exemplified with lower and slower (40-50 min) CAF oxidation or was not achieved (30 wt. \% CuO, $\mathrm{P} 25)$. The other authors indicate that CAF can be efficiently (at least in $95 \%$ ) removed after longer treatment time: $40 \mathrm{~min}$ [92] or even $240 \mathrm{~min}$ [93].

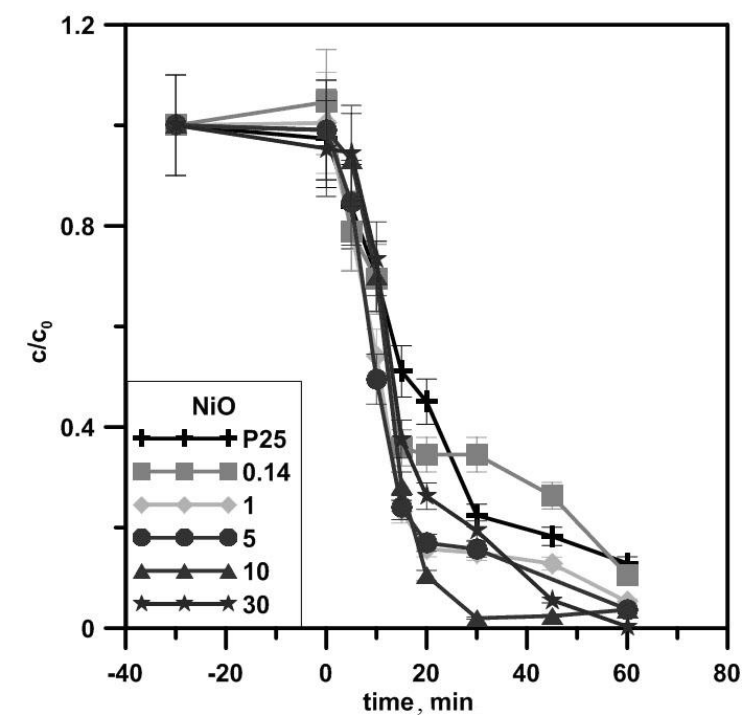

Fig. 11. The photocatalytic destruction of CAF $(10 \mathrm{mg} / \mathrm{L})$ using $\mathrm{SiO}_{2} / \mathrm{TiO}_{2} / \mathrm{CuO}$ and P25 (Evonik) $(0.5 \mathrm{~g} / \mathrm{L})$ 
In contrast to $\mathrm{CuO}$-doped materials, NiOmodified $\mathrm{SiO}_{2} / \mathrm{TiO}_{2}$ systems reveal similar activity in CAF decomposition only in the early stages of treatment. After $20 \mathrm{~min}$ of photooxidation the process proceeded diversely. Doping with $\mathrm{NiO}$ over 0.14 wt. \% is shown to result in the raised destruction of CAF. The best results were obtained using $\mathrm{NiO}(10 \mathrm{wt} . \%)$ doped sample and this

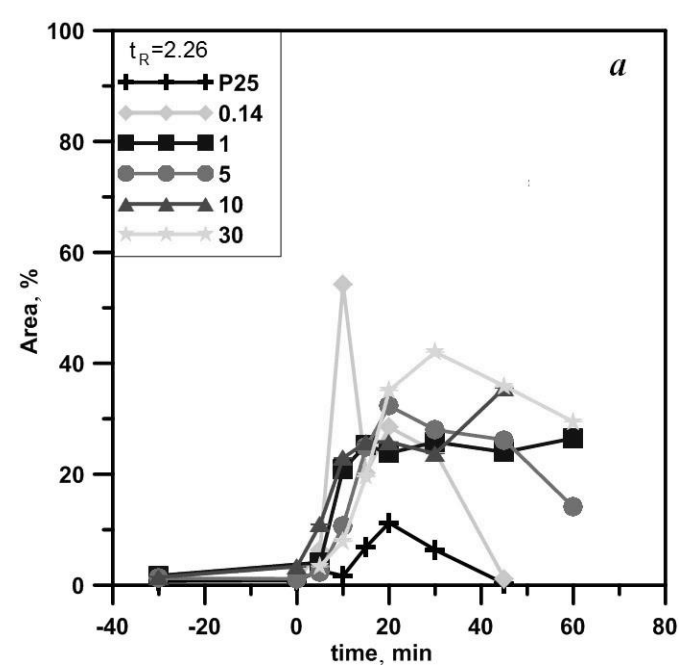

composition of $\mathrm{SiO}_{2} / \mathrm{TiO}_{2} / \mathrm{NiO}$ seems to be optimal. The significant (at least $95 \%$ removal of CAF) was observed at $\mathrm{C}_{\mathrm{NiO}}=10$ wt. $\%$ after $25 \mathrm{~min}$ or longer (60 min for other beside $0.14 \%$ and titania P25). $\mathrm{NiO}(30$ wt. \% $)-\mathrm{SiO}_{2} / \mathrm{TiO}_{2}$ destroys CAF completely similarly to $\mathrm{NiO}\left(10\right.$ wt. \%) $-\mathrm{SiO}_{2} / \mathrm{TiO}_{2}$ but it needs more time for this (60 min).

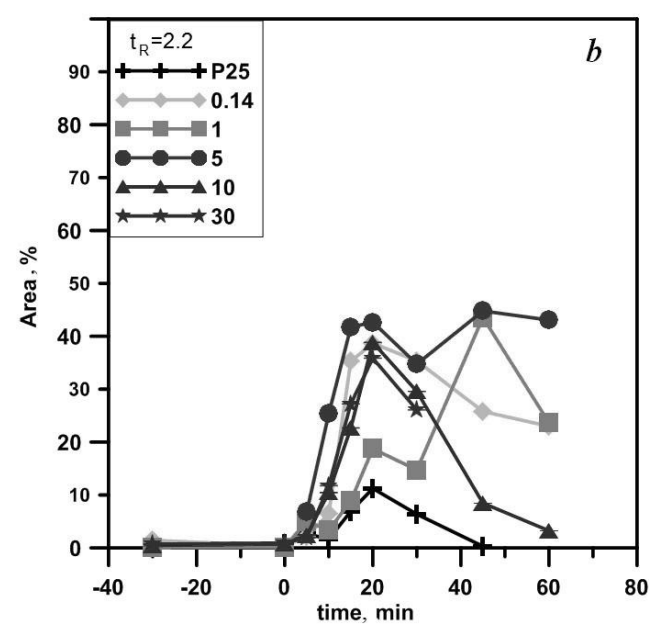

Fig. 12. Photooxidation of the main by-product by $\mathrm{SiO}_{2} / \mathrm{TiO}_{2} / \mathrm{CuO}(a)$ and $\mathrm{SiO}_{2} / \mathrm{TiO}_{2} / \mathrm{NiO}(b)$ at a $\mathrm{HPLC}$ retention time $\mathrm{t}_{\mathrm{R}}=2.2-2.26 \mathrm{~min}$

It can be stated that not only CAF but its oxidation products are oxidized further into $\mathrm{CO}_{2}$ and water. Although there are two main by-products observed, their amounts during treatment are significantly reduced or are oxidized totally and not observed. The amount of the main by-product at $\mathrm{t}_{\mathrm{R}}=2.2 \div 2.26$ min (Fig. 12) generated over all studied photocatalysts is higher than by usage of P25 but partially associated with the amount of dopant. Only $\mathrm{NiO}\left(10\right.$ wt. \%)-SiO $2 / \mathrm{TiO}_{2}$ and $\mathrm{CuO}(0.14$ wt. \%)$\mathrm{SiO}_{2} / \mathrm{TiO}_{2}$ showed ability to destroy this by-product more active than other samples.

Kinetic studies. The decrease of CAF concentration $(c)$ during the treatment time $(t)$ was described by the pseudo first-order kinetics based on equation [94]:

$\mathrm{r}=-\frac{\mathrm{dc}}{\mathrm{dt}}=\mathrm{kc}$,

where $r$ and $t$ represent the rate of degradation and time respectively. Also $k$ and $n$ are the rate constant and reaction order.

To simplify the heterogeneous photocatalytic process the initial concentration of the organic substrate $c_{0}$ was kept constant. The apparent pseudo first-order rate constant $\left(\mathrm{min}^{-1}\right) k_{l}$ was obtained by fitting the experimental data from the relation (Eq. 7):

$-\ln \left(\frac{\mathrm{c}}{\mathrm{c}_{0}}\right)=\mathrm{k}_{1} \cdot \mathrm{t} \cdot$

The linear regressions obtained by plotting $\ln \left(c / c_{0}\right)$ vs. time were used for the evaluation of $k_{l}$. The other constants: apparent rate constants of the catalyst per mass units $\left(k_{w}\right)$ and per surface area units $\left(k_{s}\right)$ were estimated from Eqs. 8 and 9 [95]:

$$
\begin{aligned}
& \mathrm{k}_{\mathrm{w}}=\frac{\mathrm{k}_{1}}{\mathrm{c}_{\mathrm{w}} \cdot \mathrm{V}_{\mathrm{r}}}, \\
& \mathrm{k}_{\mathrm{s}}=\frac{\mathrm{k}_{1}}{\mathrm{~S}_{\text {BET }} \cdot \mathrm{c}_{\mathrm{w}} \cdot \mathrm{V}_{\mathrm{r}}},
\end{aligned}
$$

where $c_{w}$ was the concentration of the photocatalysts, $S_{B E T}$ - specific surface area of photocatalyst and $V_{r}$ - the reactor volume $(0.75 \mathrm{~L})$. Subsequently, half-life values were calculated using Eq. 10:

$$
\mathrm{t}_{1 / 2}=\frac{0.69314}{\mathrm{k}_{1}} \text {. }
$$



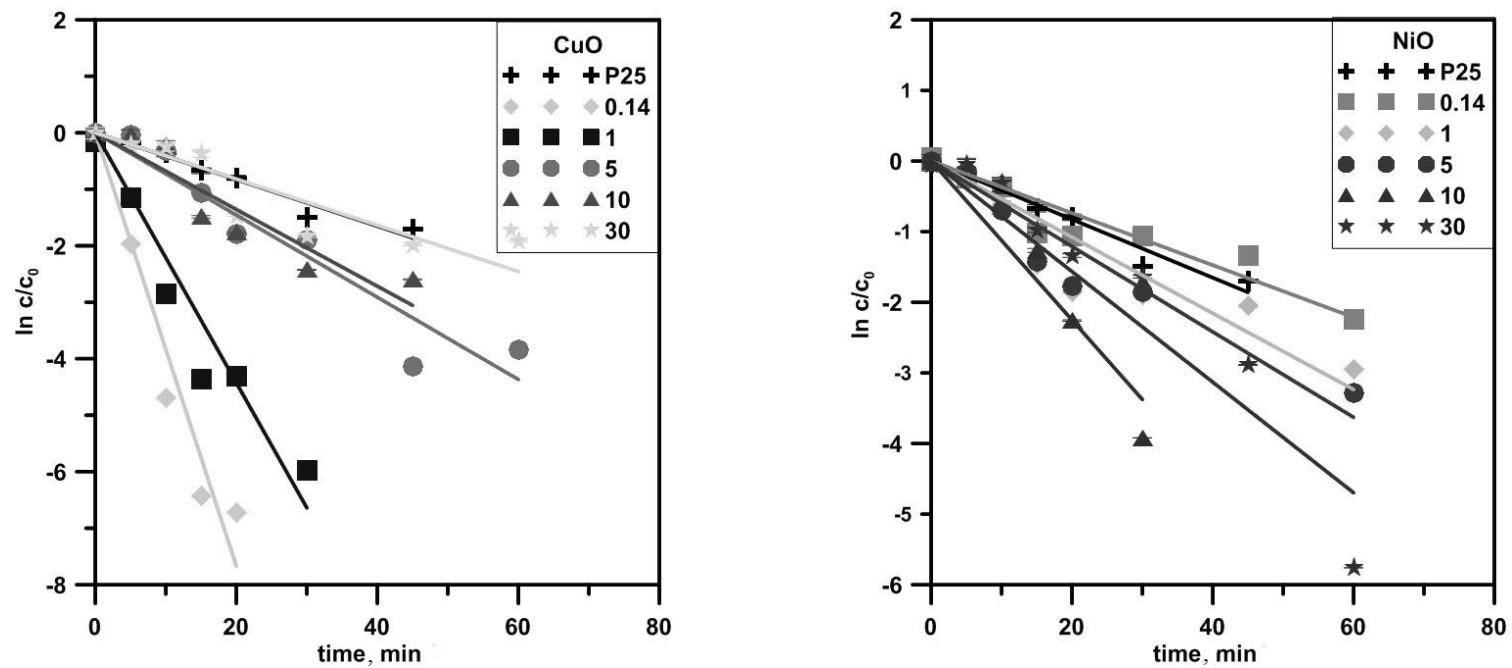

Fig. 13. The kinetics of $\mathrm{CAF}(10 \mathrm{mg} / \mathrm{L})$ photooxidation using $\mathrm{SiO}_{2} / \mathrm{TiO}_{2} / \mathrm{CuO}$ and $\mathrm{SiO}_{2} / \mathrm{TiO}_{2} / \mathrm{NiO}$ photocatalysts $(0.5 \mathrm{~g} / \mathrm{L})$

Table 3. Pseudo first-order reaction rate constants $\left(k_{l}\right)$ per gram of catalyst $\left(k_{w}\right)$ and per surface area of catalyst $\left(k_{s}\right)$ of the photocatalytic oxidation of CAF

\begin{tabular}{|c|c|c|c|c|c|c|}
\hline Photocatalyst & $\begin{array}{c}k_{l}, \\
10^{-2} \min ^{-1}\end{array}$ & $R^{2}$ & $\begin{array}{c}k_{W}, \\
10^{-2} \mathrm{~min}^{-1} \cdot \mathrm{g}^{-1}\end{array}$ & $\begin{array}{c}S_{B E T,}, \\
\mathrm{~m}^{2} \cdot \mathrm{g}^{-1}\end{array}$ & $\begin{array}{c}k_{S,} \\
10^{-3} \mathrm{~min}^{-1} \cdot \mathrm{m}^{-2}\end{array}$ & $\begin{array}{l}t_{1 / 2}, \\
\text { min }\end{array}$ \\
\hline $\mathrm{P} 25$ & 4.132 & 0.985 & 11.02 & 55 & 2.004 & 16.78 \\
\hline \multicolumn{7}{|l|}{$\mathrm{C}_{\mathrm{CuO}}$, wt. $\%$ : } \\
\hline 0.14 & 18.172 & 0.838 & 48.46 & 289 & 1.676 & 3.81 \\
\hline 1 & 22.134 & 0.912 & 59.02 & 245 & 2.414 & 3.13 \\
\hline 5 & 7.279 & 0.963 & 19.41 & 278 & 0.697 & 9.52 \\
\hline 10 & 6.790 & 0.942 & 18.11 & 256 & 0.707 & 10.21 \\
\hline 30 & 4.095 & 0.913 & 10.92 & 251 & 0.436 & 16.93 \\
\hline \multicolumn{7}{|l|}{$\mathrm{C}_{\mathrm{NiO}}$, wt. \%: } \\
\hline 0.14 & 5.393 & 0.838 & 14.38 & 294 & 0.489 & 12.85 \\
\hline 1 & 3.688 & 0.912 & 9.84 & 297 & 0.332 & 18.79 \\
\hline 5 & 6.049 & 0.963 & 16.13 & 291 & 0.555 & 11.46 \\
\hline 10 & 11.260 & 0.942 & 30.03 & 266 & 1.131 & 6.16 \\
\hline 30 & 7.830 & 0.913 & 20.88 & 259 & 0.807 & 8.85 \\
\hline
\end{tabular}

Low values of coefficient of determination $\left(\mathrm{R}^{2}\right)$ for the $\mathrm{k}_{1}$ of both $0.14 \mathrm{wt}$ \% \%-doped photocatalysts may indicate that the photooxidation did not proceed exactly according to the pseudo-first order kinetics. In the time curves a two-step oxidation is observed. In the first part, the process is described as a linear correlation of $1 n c / c_{0}$ vs. time with following parameters $\mathrm{k}_{1}=0.438 \mathrm{R}^{2}=0.997$ and $\mathrm{k}_{1}=0.088$, $\mathrm{R}^{2}=0.977$ for 0.14 wt. \% $\mathrm{CuO}$ and 0.14 wt. \% NiO, respectively. After 15 and $20 \mathrm{~min}$, for $\mathrm{CuO}$ and $\mathrm{NiO}$ respectively, the breakdown can be observed and the slower destruction was achieved.

The overall improvement of the photocatalytic activity through $\mathrm{TiO}_{2}$ surface modification was confirmed by the kinetic enhancement of the treatment of CAF using all studied materials [96]. The span between lowest $k_{l}$ value $\left(\mathrm{P} 254.132 \cdot 10^{-2} \mathrm{~min}^{-1}\right)$ and the highest value $\left(22.134 \cdot 10^{-2} \mathrm{~min}^{-1}\right)$ is characterized by a factor of five. Generally, lower $k_{1}$ values were obtained for $\mathrm{NiO}$ modified photocatalysts. But $k_{w}$ values of all nanocomposites exceed ones of $\mathrm{P} 25$ except at $\mathrm{C}_{\mathrm{NiO}}=1 \mathrm{wt}$. \%.

The optimal ratio of $\mathrm{CuO}$ doping seemed to be ca. 1 wt. \% even expressed in units of $k_{s}$ taking into account surface area of $\mathrm{CuO}$ and $\mathrm{NiO}$ doped samples [97] their values of $k_{s}$ lie at the same order as of $\mathrm{P} 25$.

\section{CONCLUSIONS}

It has been shown that $\mathrm{CuO}$ and $\mathrm{NiO}$ dopants cause changes in the UV-Vis spectra profiles of silica-titania systems depending on their character and dopant concentrations. $\mathrm{CuO}$ provokes an increase in absorption in the visible light range and 
a drop in the $\mathrm{E}_{\mathrm{g}}$ value. The results indicate that the band gap narrowing is proportional to the dopant concentration growth, i.e. incorporation of $\mathrm{CuO}$ may cause major efficiency of titania as catalysis even dispersed in nanosilica matrix.

As regards $\mathrm{NiO}$, this dopant stimulates the reduction of the $\mathrm{E}_{\mathrm{g}}$ almost in linear way. There are two absorption edges in the DRS spectra at $\mathrm{C}_{\mathrm{NiO}}=30 \mathrm{wt}$. \% supporting supposition of rutile and nickel titanate $\left(\mathrm{NiTiO}_{3}\right)$ formation. Thus, the synthesized composite may be important for different catalytic applications. There is a monotonous increase in the visible light absorption by the augmentation of $\mathrm{NiO}$ concentration.

According to XPS data, both dopants are absent at the composite surface and the signals of the highest intensities were found to belong to silica and oxygen. It corroborates the suggestion of oxide dopants presence within the thickness (>3 nm beneath the surface) of the synthesized silica-titania composites.

The photocatalysis study results revealed that all the samples are found to be more effective in photocatalytic oxidation of caffeine (CAF) than reference titania P25 except $\mathrm{NiO}(1$ wt. \%)-doped $\mathrm{SiO}_{2} / \mathrm{TiO}_{2}$. The most significant changes in the water quality were observed after $15 \mathrm{~min}$ of treatment. It is vital to note that the samples contain titania at $\mathrm{C}_{\mathrm{TiO} 2}=15$ wt. \% compared to pure $\mathrm{TiO}_{2}$ produced by Degussa. This lets us assume that their efficiency is appreciably higher than that of P25.

A sample at $\mathrm{C}_{\mathrm{CuO}}=10 \mathrm{wt} . \%$ and $\mathrm{P} 25$ are indicated to demonstrate similar abilities to decompose model contaminant. $\mathrm{CuO}(1 \mathrm{wt}$ \%)containing system shows the highest activity as photocatalyst, that provides reason to conclude that the most sufficient $\mathrm{TiO}_{2}$-based photocatalysts can incorporate crystalline anatase and rutile phases together.

Photooxidation of CAF caused by NiO-doped nanomaterials was observed for all samples beside one at $\mathrm{C}_{\mathrm{NiO}}=1 \mathrm{wt}$. $\%$ as noted above. What matters here is that the optimal concentration of $\mathrm{NiO}$ where enhancement of CAF destruction has been observed is $10 \mathrm{wt}$. \%.

The formation of by-products of CAF oxidation in the presence of all photocatalysts is established. An important point is that their amounts are reduced during the experiment for $60 \mathrm{~min}$. It needs more time to remove them completely.

Acknowledgements: The authors are grateful to the European Community, Seventh Framework Programme (FP7/2007-2013), Marie Curie International Research Staff Exchange Scheme (grants No. 230790 and 612484) for financial support.

\title{
Зміна ширини забороненої зони та фотокаталітична активність титанокремнеземів, допованих $\mathrm{CuO}$ та $\mathrm{NiO}$
}

\author{
M.O. Назарковський, В.М. Гунько, G. Wójcik, B. Czech,
} A. Sobieszek, J. Skubiszewska-Zięba, W. Janusz, E. Skwarek

\author{
Інститут хімії поверхні ім. О.О. Чуйка Національної академї наук Украӥни \\ вул. Генерала Наумова, 17, Київ, 03164, Украӥна, nazarkovsky.michael@gmail.com \\ Університет імені Марії Кюрі-Склодовської, хімічний факультет \\ пл. Марії Кюрі-Склодовської, 3, Люблін, 20031, Польща
}

Титанокремнеземні нанокомпозити, доповані $\mathrm{CuO}$ або NiO, вивчені методами ультрафріолетової (y режсимі дифузного відбиття) та рентгенівської фотоелектронної спектроскопії. Фотокаталітична активність зразків була досліджена в процесі фотоокиснення кофеїну. Значення ширини забороненої зони розраховувались методом Тауца для непрямих дозволених оптичних переходів за винятком зразка при $C_{\text {NiO }}=30$ мас. \%, проаналізованого з урахуванням прямого оптичного дозволеного переходу. Підвищення вмісту оксиду купруму(II) призводить до практично експоненціального зменшення ширини забороненої зони. Ширина забороненої зони композитів, допованих NiO, демонструє майже лінійне сниження зі зростанням $C_{\text {NiO. }}$ Згідно з даними РФЕС, допанти повністю відсутні в поверхневому шарі матеріалів. Всі композити виявились більш активними фотокаталізаторами, ніж зразок P25 (Evonik).

\footnotetext{
Ключові слова: діоксид титану, кофеїн, Р25, РФЕС, фотокаталізатори, реактор Heraеus, СиО, $\mathrm{NiO}$
} 


\title{
Изменение ширины запрещенной зоны и фотокаталитическая активность титанокремнеземов, допированных $\mathrm{CuO}$ и $\mathrm{NiO}$
}

\author{
М.А. Назарковский, В.М. Гунько, G. Wójcik, B. Czech, \\ A. Sobieszek, J. Skubiszewska-Zięba, W. Janusz, E. Skwarek
}

\begin{abstract}
Институт химии поверхности им. А.А. Чуйко Национальной академии наук Украины ул. Генерала Наумова, 17, Киев, 03164, Украина, nazarkovsky.michael@ gmail.com Университет имени Марии Кюри-Склодовской, химический факультет пл. Марии Кюри-Склодовской, 3, Люблин, 20031, Польша
\end{abstract}

\begin{abstract}
Титанокремнеземные нанокомпозиты, допированные $\mathrm{CuO}$ или $\mathrm{NiO}$, изучены посредством ультрафиолетовой (в режиме диффузного отражения) и рентгеновской фотоэлектронной спектроскопии. Фотокаталитическая активность образиов исследовалась в процессе фотоокисления кофеина. Значения ширины запрещенной зоны рассчитывались методом Тауиа для непрямых разрешенных оптических переходов за исключением образиа при $C_{N i O}=30$ масс. \%, который был проанализирован с учетом прямого оптического разрешенного перехода. Возрастание концентрации оксида меди приводит к практически экспоненциальному уменьшению ширины запрещенной зоны. Ширина запрещенной зоны композитов, допированных $\mathrm{NiO}$, демонстрирует почти линейное снижение с возрастанием $C_{\text {Niо. }}$ Согласно данным РФЭС, допанты полностью отсутствуют в поверхностном слое материалов. Все композиты более эффективны в качестве фотокатализаторов, чем образеи P25 (Evonik).
\end{abstract}

Ключевые слова: диоксид титана, кофеин, Р25, РФЭС, фотокатализаторы, реактор Hегаеи, $\mathrm{CuO}, \mathrm{NiO}$

\section{REFERENCES}

1. Bernik S., Daneu N., Recnik A. Inversion boundary induced grain growth in $\mathrm{TiO}_{2}$ or $\mathrm{Sb}_{2} \mathrm{O}_{3}$ doped $\mathrm{ZnO}$-based varistor ceramics, J. Eur. Ceram. Soc., 24 (2004) 3703.

2. Cruz A.M., Reyes Y., Gallego B. et al. Control of microstructure in $\mathrm{TiO}_{2}$-doped ceremaic varistors based on $\mathrm{ZnO}-\mathrm{Bi}_{2} \mathrm{O}_{3}-\mathrm{Sb}_{2} \mathrm{O}_{3}$ system, Bol. Soc. Esp. Ceram. Vidrio, 51 (2012) 61

3. Gotfredson K., Wennerberg A., Johansson C. et al. Anchorage of $\mathrm{TiO}_{2}$-blasted, HA-coated, and machined implants: An experimental study with rabbits, J. Biomed. Mater. Res., 29 (1995) 1223.

4. Hosseinnia A., Keyanpour-Rad M., Pazouki M. Photo-catalytic Degradation of Organic Dyes with Different Chromophores by Synthesized Nanosize $\mathrm{TiO}_{2}$ Particles, World Applied Sciences Journal, 8(2010) 1327.

5. Kar A., Raja K.S., Misra M. Electrodeposition of hydroxyapatite onto nanotubular $\mathrm{TiO}_{2}$ for implant applications, Surface and Coatings Technology, 201 (2006) 3723.

6. Konstantinou I.K., Albanis T.A. $\mathrm{TiO}_{2}$-assisted photocatalytic degradation of azo dyes in aqueous solution: kinetic and mechanistic investigations: A review, Applied Catalysis B: Environmental, 49 (2004) 1.

7. Kozhukharov S., Nenova Z., Nenov T., Ivanov S. Influence of dopants on the performance of humidity sensitive elements, prepared by deposition of $\mathrm{TiO}_{2}$ via sol-gel method, Annual proceedings of "Angel Kanchev" University of Russe, 2010. Bulgaria.

8. Lee J., Dong X., Dong X. Ultrasonic synthesis and photocatalytic characterization of $\mathrm{H}_{3} \mathrm{PW}_{12} \mathrm{O}_{40} / \mathrm{TiO}_{2}$ (anatase), Ultrasonics Sonochemistry, 17 (2010) 649.

9. Lee S.-H., Kim H.-W., Lee E.-J. et al. Hydroxyapatite- $\mathrm{TiO}_{2}$ Hybrid Coating on $\mathrm{Ti}$ implants, J. Biomater. Appl., 20 (2006) 195.

10. Nenov T., Kozhukharov S., Nenova Z., Machkova M. Impact of dopants on the characteristics of thin film humidity sensor elements, "Sensor + Test" Conference. 2011, Germany.

11. Tian L., Ye L., Deng K., Zan L. $\mathrm{TiO}_{2} /$ carbon nanotube hybrid nanostructures: Solvothermal synthesis and their visible light photocatalytic activity, J. Solid State Chem., 184 (2011) 1465.

12. Uzunova-Bujnova M., Kralchevska R., Milanova $M$. et al. Crystal structure, 
morphology and photocatalytic activity of modified $\mathrm{TiO}_{2}$ and of spray-deposited $\mathrm{TiO}_{2}$ films, Catal. Today, 151 (2010) 14.

13. Vohra M.S., Davis A.P. $\mathrm{TiO}_{2}$-Assisted photocatalysis of lead-EDTA, Water Res., 34 (2000) 952.

14. Zubillaga O., Cano F.J., Azkarate I. et al. Synthesis of anodic films in the presence of aniline and $\mathrm{TiO}_{2}$ nanoparticles on AA2024-T3 aluminium alloy, Thin Solid Films, 517 (2009) 6742.

15. Shiraishi K., Koseki H., Tsurumoto T. et al. Antibacterial metal implant with a $\mathrm{TiO}_{2^{-}}$ conferred photocatalytic bactericidal effect against Staphylococcus aureus, Surf. Interface Anal., 41 (2009) 17.

16. Burda C., Lou Y., Chen X. et al. Enhanced Nitrogen Doping in $\mathrm{TiO}_{2}$ Nanoparticles, Nano Letters, 3 (2003) 1049.

17. Cao Y., Yang W., Zhang W. et al. Improved photocatalytic activity of $\mathrm{Sn}^{4+}$ doped $\mathrm{TiO}_{2}$ nanoparticulate films prepared by plasmaenhanced chemical vapor deposition, New J. Chem., 28 (2004) 218.

18. Choi W., Termin A., Hoffmann M.R. The Role of Metal Ion Dopants in Quantum-Sized $\mathrm{TiO}_{2}$ : Correlation between Photoreactivity and Charge Carrier Recombination Dynamics, J. Phys. Chem., 98 (1994) 13669.

19. Gai Y., Li J., Li S.-S. et al. Design of NarrowGap $\mathrm{TiO}_{2}$ : A Passivated Codoping Approach for Enhanced Photoelectrochemical Activity, Phys. Rev. Lett., 102 (2009) 036402.

20. Lindgren T.r., Mwabora J.M., Avenda E. et al. Photoelectrochemical and Optical Properties of Nitrogen Doped Titanium Dioxide Films Prepared by Reactive DC Magnetron Sputtering, J. Phys. Chem. B, 107 (2003) 5709.

21. Yun H.J., Lee H., Joo J.B. et al. Tuning the band-gap energy of $\mathrm{TiO}_{2-\mathrm{x}} \mathrm{C}_{\mathrm{x}}$ nanoparticle for high performance photo-catalyst, Electrochemistry Communications, 12 (2010) 769.

22. Zhu W., Qiu X., Iancu V. et al. Band Gap Narrowing of Titanium Oxide Semiconductors by Noncompensated Anion-Cation Codoping for Enhanced Visible-Light Photoactivity, Phys. Rev. Lett., 103 (2009) 226401.

23. Bakry A. Dispersion and Fundamental Absorption Edge Analysis of Doped a-Si:H thin Films, Egyptian Journal of Solids, 31 (2008) 191.

24. Madhusudan Reddy K., Manorama S.V., Ramachandra Reddy A. Bandgap studies on anatase titanium dioxide nanoparticles, Materials Chemistry and Physics, 78 (2003) 239.

25. Murphy A.B. Band-gap determination from diffuse reflectance measurements of semiconductor films, and application to photoelectrochemical water-splitting, Sol. Energy Mater., 91 (2007) 1326.

26. Singh R.S., Bhushan S., Singh A.K., Deo S.R. Characterization and optical properties of CgSe Nano-crystalline thin films, Digest Journal of Nanomaterials and Biostructures, 6 (2011) 403.

27. Artem'ev Y.M., Ryabchuk V.K. Introduction to Heterogeneous Photocatalysis, St. Petersburg Ed. 1999, St. Petersburg. 304.

28. Henglein A., Fojtik A., Weller H., Bunsenges B. Reactions on colloidal Semiconductor particles, J. Phys. Chem., 91 (1987) 441.

29. Hoffmann H., Henglein A. Q-particles: Size quantization effects in colloidal semiconductors, New Trends in Colloid Science, H. Hoffmann, Ed., 1987, Steinkopff, P. 1-3.

30. Spanhel L., Haase M., Weller H., Henglein A. Photochemistry of colloidal semiconductors. 20. Surface modification and stability of strong luminescing CdS particles, J. Am. Chem. Soc., 109 (1987) 5649.

31. Weller $H$. Colloidal Semiconductor QParticles: Chemistry in the Transition Region Between Solid State and Molecules, Angew. Chem., Int. Ed., 32 (1993) 41.

32. Brus L. Electronic wave functions in semiconductor clusters: experiment and theory, J. Phys. Chem., 90 (1986) 2555.

33. Kayanuma $Y$. Quantum-size effects of interacting electrons and holes in semiconductor microcrystals with spherical shape, Physical Review B, 38 (1988) 9797.

34. Franceschetti A., Zunger A. Direct Pseudopotential Calculation of Exciton Coulomb and Exchange Energies in Semiconductor Quantum Dots, Phys. Rev. Lett., 78 (1997) 915.

35. Senger R.T., Bajaj K.K. Optical properties of confined polaronic excitons in spherical ionic quantum dots, Physical Review B, 68 (2003) 045313.

36. Uozumi T., Kayanuma $Y$. Excited states of an electron-hole pair in spherical quantum dots and their optical properties, Physical Review B, 65 (2002) 165318. 
37. Vatankhah C., Ebadi A. Quantum Size Effects on Effective Mass and Band gap of Semiconductor Quantum Dots, Res. J. Recent Sci., 2 (2013) 21.

38. Guo M., Du J. First-principles study of electronic structures and optical properties of $\mathrm{Cu}, \mathrm{Ag}$, and Au-doped anatase $\mathrm{TiO}_{2}$, Physica B: Condensed Matter, 407 (2012) 1003.

39. Reyes-Coronado D., Rodriguez-Gattorno G., Espinosa-Pesqueira M.E. et al. Phase-pure $\mathrm{TiO}_{2}$ nanoparticles: anatase, brookite and rutile, Nanotechnology, 19 (2008) 145605.

40. Bonch V.L., Kalashnikov S.G. Physics of Semiconductors, 2 ed., Nauka, 1990, Moscow. $678 \mathrm{p}$.

41. Ignatov A.N. Optoelectronic instruments ans devices, Electrotrends, 2006, Moscow. 272.

42. Rafferty B., Brown L.M. Direct and indirect transitions in the region of the band gap using electron-energy-loss spectroscopy, Physical Review B., 58 (1998) 10326.

43. Carballa M., Omil F., Ternes T., Lema J.M. Fate of pharmaceutical and personal care products (PPCPs) during anaerobic digestion of sewage sludge, Water Res., 41 (2007) 2139.

44. Ellis J.B. Pharmaceutical and personal care products (PPCPs) in urban receiving waters, Environ. Pollut., 144 (2006) 184.

45. Mohapatra D.P., Brar S.K., Tyagi R.D. et al. Analysis and advanced oxidation treatment of a persistent pharmaceutical compound in wastewater and wastewater sludgecarbamazepine, Sci. Total Environ., 470-471 (2014) 58.

46. Diamanti-Kandarakis E., Bourguignon J.-P., Giudice L.C. et al. Endocrine-Disrupting Chemicals: An Endocrine Society Scientific Statement, Endocrine Reviews, 30 (2009) 293.

47. Lapworth D.J., Baran N., Stuart M.E., Ward R.S. Emerging organic contaminants in groundwater: A review of sources, fate and occurrence, Environ. Pollut., 163 (2012) 287.

48. Xu J., Wu L., Chang A.C. Degradation and adsorption of selected pharmaceuticals and personal care products (PPCPs) in agricultural soils, Chemosphere, 77 (2009) 1299.

49. Wu X., Ernst F., Conkle J.L., Gan J. Comparative uptake and translocation of pharmaceutical and personal care products (PPCPs) by common vegetables, Environment International, 60 (2013) 15.

50. Yang B., Ying G.-G., Zhao J.-L. et al. Removal of selected endocrine disrupting chemicals
(EDCs) and pharmaceuticals and personal care products (PPCPs) during ferrate(VI) treatment of secondary wastewater effluents, Water Res., 46 (2012) 2194.

52. Weigel S., Kuhlmann J., Huhnerfuss $H$. Drugs and personal care products as ubiquitous pollutants: occurrence and distribution of clofibric acid, caffeine and DEET in the North Sea, Sci. Total Environ., 295 (2002) 131.

53. Bruton T., Alboloushi A., Garza de la B. et al. Fate of Caffeine in the Environment and Ecotoxicological Considerations, Contaminants of Emerging Concern in the Environment: Ecological and Human Health Considerations, R.U. Halden, Edi. 2010, American Chemical Society, 257-273.

54. Sauve S., Aboulfadl K., Dorner S. et al. Fecal coliforms, caffeine and carbamazepine in stormwater collection systems in a large urban area, Chemosphere, 86 (2012) 118.

55. Ananpattarachai J., Kajitvichyanukul $P$., Seraphin $S$. Visible light absorption ability and photocatalytic oxidation activity of various interstitial $\mathrm{N}$-doped $\mathrm{TiO}_{2}$ prepared from different nitrogen dopants, J. Hazard. Mater., 168 (2009) 253.

56. Paz Y. Application of $\mathrm{TiO}_{2}$ photocatalysis for air treatment: Patents' overview, Applied Catalysis B: Environmental, 99 (2010) 448.

57. Cao S., Yeung K.L., Yue P.-L. An investigation of trichloroethylene photocatalytic oxidation on mesoporous titania-silica aerogel catalysts, Applied Catalysis B: Environmental, 76 (2007) 64.

58. Pinho L., Mosquera M.J. Titania-Silica Nanocomposite Photocatalysts with Application in Stone Self-Cleaning, J. Phys. Chem. C, 115 (2011) 22851.

59. Li Z., Нои B., Хи Y. et al. Comparative study of sol-gel-hydrothermal and sol-gel synthesis of titania-silica composite nanoparticles, J. Solid State Chem., 178 (2005) 1395.

60. Xie C., Хu Z., Yang Q. et al. Enhanced photocatalytic activity of titania-silica mixed oxide prepared via basic hydrolyzation, Materials Science and Engineering: B, 112 (2004) 34.

61. Khalil K.M.S., Elsamahy A.A., Elanany M.S. Formation and Characterization of High Surface Area Thermally Stabilized Titania/Silica Composite Materials via Hydrolysis of Titanium(IV) tetra-Isopropoxide 
in Sols of Spherical Silica Particles, J. Colloid Interface Sci., 249 (2002) 359.

62. Mohamed M.M., Salama T.M., Yamaguchi T. Synthesis, characterization and catalytic properties of titania-silica catalysts, Colloids and Surfaces A: Physicochemical and Engineering Aspects, 207 (2002) 25.

63. Zhang X., Zhang F., Chan K.-Y. Synthesis of titania-silica mixed oxide mesoporous materials, characterization and photocatalytic properties, Applied Catalysis A: General, 284 (2005) 193.

64. Hilonga A., Kim J.-K., Sarawade P.B., Kim H.T. Titania-silica composites with less aggregated particles, Powder Technol., 196 (2009) 286.

65. Gao X., Wachs I.E. Titania-silica as catalysts: molecular structural characteristics and physico-chemical properties, Catal. Today, 51 (1999) 233.

66. Byrne H.E., Mazyck D.W. Removal of trace level aqueous mercury by adsorption and photocatalysis on silica-titania composites, J. Hazard. Mater., 170 (2009) 915.

67. Zhang H., Quan X., Chen S., Zhao $H$. Fabrication and Characterization of Silica/Titania Nanotubes Composite Membrane with Photocatalytic Capability, Environmental Science \& Technology, 40 (2006) 6104.

68. Wang P., Du M., Zhang M. et al. The preparation of tubular heterostructures based on titanium dioxide and silica nanotubes and their photocatalytic activity, Dalton Transactions, 43 (2014) 1846.

69. Kubelka P., Munk F. Ein Beitrag zur Optik der Farbanstriche, Zeitschrift für technische Physik, 12 (1931) 593.

70. Buchholz D.B., Liu J., Marks T.J. et al. Control and Characterization of the Structural, Electrical, and Optical Properties of Amorphous Zinc-Indium-Tin Oxide Thin Films, ACS Applied Materials \& Interfaces, 1 (2009) 2147.

71. Tauc J., Grigorovici R., Vancu A. Optical Properties and Electronic Structure of Amorphous Germanium, Physica Status Solidi (B), 15 (1966) 627.

72. Nagao Y., Yoshikawa A., Koumoto K. et al. Experimental characterization of the electronic structure of anatase $\mathrm{TiO}_{2}$ : Thermopower modulation, Appl. Phys. Lett., 97 (2010) 172112.
73. Venkatachalam N., Palanichamy M., Murugesan $V$. Sol-gel preparation and characterization of nanosize $\mathrm{TiO}_{2}$ : Its photocatalytic performance, Mater. Chem. Phys., 104 (2007) 454.

74. Mohammadi M.R., Fray D.J. Mesoporous and nanocrystalline sol-gel derived $\mathrm{NiTiO}_{3}$ at the low temperature: Controlling the structure, size and surface area by Ni:Ti molar ratio, Solid State Sciences, 12 (2010) 1629.

75. Nazarkovsky M.A., Goncharuk E.V., Pakhlov E.M. et al. Synthesis and Properties of Composites Synthesized by Deposition of $\mathrm{TiO}_{2}$ Doped with $\mathrm{SnO}_{2}$ or NiO onto A-300 Nanosilica, Protection of Metals and Physical Chemistry of Surfaces, 49 (2013) 541.

76. Riyas S., Krishnan G., Mohan Das P.N. Rutilation in nickel oxide-doped titania prepared by different methods, Ceramics International, 32 (2006) 593.

77. Serikov A.S., Gladkov V.E., Zherebtsov D.A. et $a l$. Formation of nickel titanate in the system of smallsized oxide of $\mathrm{TiO}_{2}$ (anatase) and $\mathrm{NiO}$, Vestnik of the SUSU, 31 (2010) 97.

78. de Haart L.G.J., de Vries A.J., Blasse G. Photoelectrochemical properties of $\mathrm{MgTiO}_{3}$ and other titanates with the ilmenite structure, Mater. Res. Bull., 19 (1984) 817.

79. Lin Y.-J., Chang Y.-H., Yang W.-D., Tsai B.-S. Synthesis and characterization of ilmenite $\mathrm{NiTiO}_{3}$ and $\mathrm{CoTiO}_{3}$ prepared by a modified Pechini method, J. Non-Cryst. Solids, 352 (2006) 789.

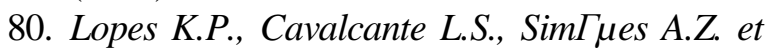
al. $\mathrm{NiTiO}_{3}$ powders obtained by polymeric precursor method: Synthesis and characterization, J. Alloys Compd., 468 (2009) 327.

81. Shu X., He J., Chen D. Visible-Light-Induced Photocatalyst Based on Nickel Titanate Nanoparticles, Ind. Eng. Chem. Res., 47 (2008) 4750.

82. Zhou G.-W., Kang Y.S. Synthesis and Characterization of the Nickel Titanate $\mathrm{NiTiO}_{3}$ Nanoparticles in CTAB Micelle, J. Disp. Sci. Technol., 27 (2006) 727.

83. Lever A.B.P. Inorganic electronic spectroscopy, V. 2., Elsevier, 1984, Amsterdam, 445 p.

84. Ganesh I., Gupta A.K., Kumar P.P. et al. Preparation and Characterization of Ni-Doped $\mathrm{TiO}_{2}$ Materials for Photocurrent and Photocatalytic Applications, The Scientific World Journal, 2012 (2012) 127326. 
85. Vijayalakshmi R., Rajendran $V$. Effect of Reaction Temperature on Size and Optical Properties of $\mathrm{NiTiO}_{3}$ Nanoparticles, E-Journal of Chemistry, 9 (2012) 282.

86. Nazarkovsky M.A., Goncharuk E.V., Pakhlov E.M. et al. Synthesis and properties of CuOmodified titania composites deposited on nanosilica A-300 surface, Chemistry, Physics and Technology of Surface, 3 (2012) 172.

87. Carley A.F., Jackson S.D., O'Shea J.N., Roberts M.W. The formation and characterisation of $\mathrm{Ni}^{3+}-$ an X-ray photoelectron spectroscopic investigation of potassium-doped Ni(110)-O, Surf. Sci., 440 (1999) 868.

88. Moroney L.M., Smart R.S.C., Roberts M.W. Studies of the thermal decomposition of betaNiO $(\mathrm{OH})$ and nickel peroxide by X-ray photoelectron spectroscopy, J. Chem. Soc. Faraday Trans. 1, 79 (1983) 1769.

89. Roberts M.W., Smart R.S.C. The defect structure of nickel oxide surfaces as revealed by photoelectron spectroscopy, J. Chem. Soc., Faraday Trans. 1, 80 (1984) 2957.

90. Rivas J., Gimeno O., Borralho T., Sagasti J. UV-C and UV-C/peroxide elimination of selected pharmaceuticals in secondary effluents, Desalination, 279 (2011) 115.

90. Rivas J., Gimeno O., Borralho T., Sagasti J. UV-C and UV-C/peroxide elimination of selected pharmaceuticals in secondary effluents, Desalination, 279 (2011) 115.

91. Qi F., Chu W., Хи B. Catalytic degradation of caffeine in aqueous solutions by cobalt-
MCM41 activation of peroxymonosulfate, Applied Catalysis B: Environmental, 134-135 (2013) 324.

92. Klamerth N., Miranda N., Malato S. et al. Degradation of emerging contaminants at low concentrations in MWTPs effluents with mild solar photo-Fenton and $\mathrm{TiO}_{2}$, Catal. Today, 144 (2009) 124.

93. Alvarez P.M., Jaramillo J., Lopez-Pinero F., Plucinski P.K. Preparation and characterization of magnetic $\mathrm{TiO}_{2}$ nanoparticles and their utilization for the degradation of emerging pollutants in water, Applied Catalysis B: Environmental, 100 (2010) 338.

94. Herrmann J.-M. Photocatalysis fundamentals revisited to avoid several misconceptions, Applied Catalysis B: Environmental, 99 (2010) 461.

95. Czech B., Rubinowska K. $\mathrm{TiO}_{2}$-assisted photocatalytic degradation of diclofenac, metoprolol, estrone and chloramphenicol as endocrine disruptors in water, Adsorption, 19 (2013) 619.

96. Choi J., Lee H., Choi Y. et al. Heterogeneous photocatalytic treatment of pharmaceutical micropollutants: Effects of wastewater effluent matrix and catalyst modifications, Applied Catalysis B: Environmental, 147 (2014) 8.

97. Nazarkovsky M.A., Goncharuk E.V., Pakhlov E.M. et al. Effect of doping with copper(II) and nickel(II) oxides on morphological properties of silica/titania nanocomposites, Chemistry, Physics and Technology of Surface, 3 (2012) 386.

Поступила 31.07.2014, принята 17.09.2014 